\title{
ATRN wt Allele
}

National Cancer Institute

\section{Source}

National Cancer Institute. ATRN wt Allele. NCI Thesaurus. Code C116673.

Human ATRN wild-type allele is located in the vicinity of $20 \mathrm{p} 13$ and is approximately 180 $\mathrm{kb}$ in length. This allele, which encodes attractin protein, plays a role in both lig and binding and inflammation. 